Ząbkowicz J., The single market and the "bicycle theory" of the European Union politics. Does it still work?, „Ekonomia i Prawo. Economics and Law”, Polszakiewicz B., Boehlke J. (ed.), Vol. 14, No. 4/2015, pp. 503-516. DOI: http://dx.doi.org/10.12775/EiP.2015.033.

\title{
THE SINGLE MARKET AND THE "BICYCLE THEORY" OF THE EUROPEAN UNION POLITICS. DOES IT STILL WORK?
}

\author{
SUMMARY
}

Decades of liberalization have transformed the original structure of the EC common market, being a synonym of the validity of the Four Freedoms - free movement of persons, goods, services and capital - into an integral instrument for conducting EU economic policy, but not without many constraints, both formal and informal.

The process of globalization of the world economy means, in the opinion of EU institutions, that currently the European Union more than ever needs a single market that would support reforms to boost growth and increase its competitiveness. The Single Market Acts of 2011 and 2012 suggest measures to further its development. It is treated as a continuous process. However, for many Member States the evolution of the single market is a kind of a perpetual transaction - a tender, in which a concession to EU group interests is expected equivalent of particular benefit. Quite often all concessions are treated by public authorities as downright harmful to the national interest, especially in times of economic and financial crisis.

The aim of this paper is an attempt to answer the question why building consensus on further proceeding to the single market is seemingly more difficult to achieve than ever in the past? The problem looks even more serious, once we accept as a start-

" Jerzy Ząbkowicz, independent researcher, phone: +48 602488 274, e-mail: j.zabkowicz@ yahoo.com. 
ing point the "bicycle theory", which shows that the halting of the evolution of the single market may cause the opposite process - the disintegration of the EU market. Keywords: single market; common market; European integration; European Union; bicycle theory

JEL Classification: F15; F42; F43; K23; K33; O43

\section{INTRODUCTION}

The concept, now known as the single market of the European Union for the first time appeared in 1957 in the Treaty establishing the European Economic Community. Establishing the Community, the parties considered its task to promote a harmonious development of economic activities, a continuous and balanced expansion, an increased stability, an accelerated raising of the standard of living and closer relations between Member States (Article 2 of the Treaty). An instrument for the achievement of these objectives was to be, next to the progressive approximation of the economic policies, the establishment of the common market. 12-year transitional period divided into three stages of four years each was considered sufficient to become operational the mechanism of a common market based on the Four Freedoms - the free movement of goods, of workers, of services, and of capital ${ }^{1}$. A key role has been entrusted to the Customs Union. The proper functioning of the common market were to support the provisions relating to competition rules and State aid.

The single market of the European Union - the successor of the common market - is now, more than half a century since the creation of the EEC, a completely different structure. It is supported by new treaties and very extensive secondary legislation. Does this mean, however, that the process of evolution may be regarded as completed? The aim of this paper is calling attention to the fact that, although all the actors of the EU's political and economic scene agree that the current structure and mechanisms of the single market require changes, however, there is a lack of consensus on the direction of further legislative action. Quite common are opinions that integration is already too far advanced and incapacitates public authorities. In contrast to this position, the EU institutions, particularly the European Commission, argue that the consolidation of the single market must be continued, otherwise we risk repeating the so-called Eurosclerosis, European period of stag-

1 The last of these in guarded form. 
nation, which we managed to get out, inter alia, through the reform of the internal market ${ }^{2}$.

In this situation, the question arises whether the "bicycle theory", referenced frequently in relation to all EU policy, can be used as an argument for further reform of the EU single market? The construct says that you must aggressively keep removing barriers. In other case, that is in absence of progress there will be backsliding. If you stop pedaling your bicycle, you will fall over $^{3}$.

The analysis of the question posed was based first of all on primary sources, especially on the documents of the European Community and the European Union. It was assumed that following the main actors of the process would be helpful in tracing different aspects of the evolution from the common market to the single market. Importantly, they are the testimony to both the successes and the difficulties, delays and resistance that had and still encounter initiatives and actions aimed at deepening market integration. The final part of this paper is an attempt to identify existing barriers that make us to grow in substantial doubt as to the future of the single market.

\section{FROM THE COMMON MARKET TO THE SINGLE MARKET}

Even optimists, when characterizing in a nutshell the first two decades of the common market, are forced to use the words "incomplete", "fragmented", "defective". They do not devalue the progress in consolidation, nor the efforts of the then Member States and institutions of the EEC. The fact is, however, that many elements of the structure of the common market was at that time practically only in the form of treaty provisions, not sufficiently supported by the secondary law of the Community. The barrier was the Treaty itself, specifically - those provisions of regulations and directives governing the functioning of the common market which used to be adopted on the ba-

${ }^{2}$ In political context the term Eurosclerosis describes a period of a perceived stagnation of the integration in Europe (the 1970s and the early 1980s). In economic sense it concerns national economies and it is used to describe countries with high unemployment and slow job creation in spite of overall economic growth.

${ }^{3}$ In principle the theory popularized in the 1970s by Fred Bergsten of the Petersom Institute for International Economics is used to refute the argument that the world economy is so open now that further trade liberalization is not an important priority. According to the "bicycle theory" if you do not keep liberalizing you risk giving up all achieved gains. 
sis of unanimity during the first stage of the transitional phase ${ }^{4}$. As a result, rather than fragmentary secondary legislation there were judgments of the Court of Justice of the European Communities which have become an important driving force for the enforcement of the Treaty.

The completion of the Customs Union and the abolition in 1968 of customs duties as between Member States was a measurable step on the way to a real common market. It happened mainly due to the fact that a sufficiently precise mechanism and timetable for the reduction of customs duties has been an integral part of the treaty itself (Articles 12 to 29). However, the EEC Treaty called not only for the abolition of customs duties but also for the elimination of so called non-tariff barriers - that means quantitative restrictions and all measures having equivalent effect (Article 3 and 30) . $^{5}$ Contrary to earlier assumptions that they will be of secondary importance, at the time of the recession (the earlier mentioned Eurosclerosis) have become effective and annoying barrier in relations between Member States. Namely, in the absence of customs duties they have constituted a fundamental instrument to protect national markets, on an equal footing with public aid and maintaining the unprofitable companies, which long ago should crash ${ }^{6}$.

During the transitional period the Council was able to adopt unanimously a number of directives and regulations but thereafter, like in case of the 6th VAT directive of 1977, "momentum was lost partly through the onset of the recession, partly through a lack of confidence and vision" 7 . In many fields the situation was even worse. In the 1985 White Paper the Commission stated explicitly that restrictions on the freedom to provide services which according to the EEC Treaty should be progressively abolished during the transitional period "not only failed to be implemented during the transitional period, but over important areas failed to be implemented at all".

${ }^{4}$ Only certain implementing acts were adopted by qualified majority. Unanimity in the Council was also required to make a transition from the first to the second stage (Article 8). In the second and the third stage qualified majority was sufficient (with some exceptions for example, see: Article 111, 112, 114).

${ }_{5}$ A growing number of technical barriers including different standards for individual products adopted by Member States for (officially) health or safety reasons as well as for consumer or environmental protection was a good example of such measures. For this purpose, the opportunities given by Article 36 of the Treaty were commonly used. Article 44, used for the application of minimum prices for cross-border turnover, was no less popular.

${ }^{6}$ The Commission has identified such companies as non-viable companies. See: Commission of the European Communities, Completing the Internal Market. White Paper from the Commission to the European Council (Milan, 28-29 June 1985), COM(85) 310 final, Brussels, 14 June 1985.

7 Ibidem, par. 5.

${ }^{8}$ Ibidem, par. 6. 
Finally, the European Council recognized that such barriers to deepen the integration of the common market can not be tolerated any longer. It agreed in conclusions of the session in Copenhagen in December 1982 that one of the priority goals is "strengthening the common market and intensifying action to eliminate practices and measures which restrict trade and distort competition"9. Then, in Fountainebleau in June $1984^{10}$, the European Council considered that there is a rapid need to adopt new measures enabling a decisive simplification of formalities in trade within the EEC, harmonization of European standards and products as well as conditions of competition, opening up public contracts in the Member States to European undertakings, progressive liberalization of trade in services and implementation a common transport policy and a transport infrastructure programme of Community interest. Just a few months later, in Dublin (December 1984), the European Council once again urged to take steps to complete the internal market ${ }^{11}$.

It appears that during the Brussels' session in March 1985 the European Council finally concluded that the time for talk already passed and decided that a single large market has to be achieved by 1992. It called upon the Commission to draw up - before the EC meeting in Milan in June 1985 - action programme with a specific timetable ${ }^{12}$. The seriousness of the situation is best illustrated by the fact that the Commission got three months to prepare a report analyzing the whole situation and proposing concrete plan of action.

The White Paper submitted by the Commission to the Milan European Council listed 279 specific legislative measures to be brought into force by 1992. Specific changes to the treaties have also been proposed so as to allow the smooth process of unification of the internal market ${ }^{13}$.

As a starting point, the Commission adopted the premise that from this moment forward no new or more stringent controls or formalities relating the goods are introduced. Close coordination of policies and approximating

9 The European Council, Conclusions. Session of the European Council, Copenhagen, 3 and 4 December 1982, Dossier of the Group of the European People's Party, Luxembourg 1990, p. 189. After that session Directive 83/189/EEC was introduced in order to prevent erection of new barriers. Its provisions imposed on Member States to notify the Commission in advance of all draft regulations and standards concerning technical specifications they intend to introduce.

${ }^{10}$ Fountainebleau European Council, Bulletin of the European Communities, No. 6/1984, pp. 8-9.

${ }_{11}$ Dublin European Council, Bulletin of the European Communities, No. 12/1984, p. 18.

12 Brussels European Council, Bulletin of the European Communities, No. 3/1985, p. 12.

${ }^{13}$ It is worth noting that the 1985 White Paper uses the concept of the internal market and defines its target form as a single market or a single integrated market. 
legislations of Member States were to happen until 1992 to enable the complete elimination of internal barriers and border controls ${ }^{14}$. The Commission clearly drew attention to the practical aspect of the problem, stating that "the creation of the internal market relies in the first place on the willingness of Member States to respect the principle of free movement of goods as laid down in the Treaty"15. Unfortunately, in Commission's opinion, it has become a rule that governments, when designing new regulations containing instruments to serve national purposes, usually do not take into account the needs of the whole Community. Thus, opportunities to minimize the difficulties for relations between Member States are lost $^{16}$.

In the 1985 White Paper the Commission identified three types of barriers (physical, technical and fiscal) hindering or even preventing real integration of the internal market. It is not possible to discuss all the measures suggested by the Commission, aimed at their removal. However, the proposal for a new strategy, effectively amending the earlier harmonization approach, which was a cornerstone of the common market legislation quarter of a century is particularly noteworthy.

In the previous approach the content of harmonization was described in legislation in detail. It made any changes in regulations slow and hard to agree. According to Article 100 of the Treaty the Council could issue directives for the approximation of the laws, regulations and administrative actions of Member States which directly affected the establishment or functioning of the common market only when acting by means of a unanimous vote. The Commission took the view that a need for action under that Article will remain, but its role should be reduced even without changing the Treaty ${ }^{17}$. In the past Article 100 was used quite often just to obstruct proposals made by other Member States.

In the 1985 White Paper the Commission has taken a clear position that the days of unanimous voting on matters of the common market gone ${ }^{18}$.

The new strategy was based on the mutual recognition of Member States' standards to much greater extent than before. Legislative harmonization was

${ }^{14}$ Commission of the European Communities, op. cit., par. 46.

15 Ibidem, par .66.

16 Ibidem, par. 74.

${ }^{17}$ In many cases Article 100 was used as an additional legal base. For example, in case of veterinary and phytosanitary control it was enough to use Article 43 (qualified majority voting), however the Council regularly used, additionally, Article 100.

${ }^{18}$ It should be remembered that at that time Spain's and Portugal's accession procedure was coming to an end. Previously, Ireland, UK and Greece joined the EEC. A period of decisions of 6 countries-founders able to vote unanimously belonged to the past. 
limited to the health and safety area, if mutual recognition was not sufficient. Responsibility for setting the technical standards had to be entrusted to private standardization bodies. Such a solution "expulsed" the standardization process beyond the legislative, reducing the detail of secondary law of the Community and allowing a quicker response to technological progress.

A new strategy must be well-balanced, decided the Commission. A strategy built purely on mutual recognition would remove barriers to trade and help create a genuine common trading market, but may not be sufficient to build up an expanding market based on a global competitiveness. At the same time, says the EC, "experience has shown that the alternative of relying on a strategy based totally on harmonization would be over-regulatory, would take a long time to implement, would be inflexible and could stifle innovation" ${ }^{19}$. Unfortunately, the problem of maintaining such balance remains valid to this day and is a source of neverending legislative conflict between the Commission and many Member States.

At the same time, the 1985 White Paper does not ignore the need for action in areas of other Freedoms. The Commission draws our attention to the fact that some obstacles to free movement for the self-employed and employees within the Community still exist ${ }^{20}$. Another problem, which at that time was waiting for a solution was the issue of taxation of wage-earners who reside in one Member State and earn their income in another. Changes to the way of understanding the concept of the common market provides a statement of the Commission that the free movement of individuals must not be restricted to the workforce only. A good example would be students and their mobility, including a question of how to facilitate the academic recognition of degrees and diplomas ${ }^{21}$.

However, the removal of barriers to the single market for services and capital remained a much more serious problem. Although it was clear that according to Article 59 of the Treaty restrictions on the free supply of services within the Community shall be progressively abolished in the course of the transitional period (that has passed years ago), and according to Article 62 Member States shall not introduce any new restrictions on the freedom which has been in fact achieved, but in practice progress in the freedom to provide cross-border services has been much slower than achieved in free movement of goods. That problem concerned both the so-called traditional services

${ }^{19}$ Commission of the European Communities, op. cit., par. 64.

20 Such as the obligation to adhere to formalities which could serve to discourage such movement and cumbersome administrative procedures relating to residence permits.

${ }^{21}$ Commission of the European Communities, op. cit., par. 94. 
(first of all banking, insurance and transport) and new technologies. The Case 13/83 brought by the European Parliament (supported by the Commission) against the Council (supported by the Netherlands) for failure to act in the field of the common transport policy could be a good example of the resistance of matter. Specifically, the Parliament accused the Council of that in the field of transport policy only minimum measures have been adopted which by no means meet the requirements of the common market, and that the provisions of Article 3 (e) and Articles 74 to 84 of the EEC Treaty have not been complied with, which constitutes an infringement of the Treaty. The Council also has not reached a decision on a large number of Commission proposals on which the European Parliament long ago adopted a favorable opinion ${ }^{22}$.

Capital movements also faced a number of barriers. Quite often Member States have had to make use of the protective clauses provided for in the Treaty $^{23}$ to maintain or to reintroduce restrictions. In the 1985 White Paper the Commission's attitude towards such safeguard clauses was that they may be introduced only on the condition that they will receive authorization (for a limited period) and they will be continually reviewed and gradually abolished as the difficulties which originally justified them diminish ${ }^{24}$. So far these rules were not respected and restrictions have been abused.

Although the deadline for completion of the single market was set at 31 December 1992, it was far from complete at this point, especially (still) in area of services. However, much has already been done, including incorporation of the changes into the Treaty through the Single European Act which came into force in 1987. General direction of change is best indicated in the provisions of Article 70, under which unanimity in matters of capital movements has been limited to measures which "constitute a step back as regards the liberalization". In the light of treaty law decisions about changes in the shape of the single market were henceforth fall almost entirely by a qualified majority.

${ }^{22}$ See: Judgment of the Court of May 22, 1985, C-13/83.

${ }^{23}$ Articles 73 and 108.

${ }^{24}$ Commission of the European Communities, op. cit., par. 128. A safeguard clause enabling Member States to take protective measures when short-term capital movements of exceptional size seriously disrupted the conduct of monetary policy was introduced by Council directive of 24 June 1988 for the implementation of Article 67 of the Treaty (88/361/EEC), OJ L 178. The Directive scrapped all remaining restrictions on capital movements between residents of the Member States as of 1 July 1990. 


\section{THE SINGLE MARKET IN ITS CURRENT FORM}

The last two decades are commonly characterized as years of progressive deepening of integration in respect of the Four Freedoms. The process have been supported by successive treaties. The Maastricht Treaty of 1993 created the concept of European citizenship with a far-reaching set of rights for EU citizens. Rules abolishing most of controls on capital and payments transfers between Member States (introduced by Council Directive 88/361/EEC) got the treaty standing. The provisions of the Treaty of Amsterdam of 1999 fully covered the social and employment policy. The integration of the Schengen Acquis into the framework of the EU meant the end of an awkward system of two parallel systems of governance and hence of multi-speed integration $^{25}$. The Treaty of Lisbon of 2009, in turn, recognized energy as a matter of a specific EU competence, thus strengthening the already achieved liberalization of the energy market.

The global financial and economic crisis broke down this, as it has seemed, rather optimistic course of the process of consolidation of the single market. Dramatic conclusions of the report of the European Parliament of $2010^{26}$ and, even more, of "Monti Report" of $2010^{27}$ stated bluntly that the Union "is facing a particularly problematic time in the history of single European market integration" ${ }^{28}$. Professor Monti identified challenges that a new policy initiative to re-launch the single market would face ${ }^{29}$. Basing on the strategy with key policy recommendations he proposed, the European Commission announced in April 2011 the Single Market Act ${ }^{30}$ and then in October 2012, after a public consultation, the Single Market Act $\mathrm{II}^{31}$. The four drivers for

${ }_{25}$ Though with special opt-out arrangements for the UK. See: M. den Boer, Step by Step Progress: An Update on the Free Movement of Persons and Internal Security, http://www.infoeuropa.eurocid.pt/files/database/000024001-000025000/000024994.pdf (09.08.2015).

${ }^{26}$ European Parliament, Report on delivering a single market to consumers and citizens (2010/2011(INI)), Session document, Committee on the Internal Market and Consumer Protection, Brussels 2010.

${ }_{27}$ M. Monti, A new Strategy for the Single Market. At the Service of Europe's Economy and Society, Report to the President of the European Commission, 9 May 2010, http://ec.europa.eu/internal_market/strategy/docs/monti_report_final_10_05_2010_en.pdf (11.08.2015).

28 European Parliament, op. cit., par. 1.

29 This issue will be discussed further below.

${ }^{30}$ European Commission, Single Market Act. Twelve levers to boost growth and strengthen confidence. Working together to create new growth, Communication from the Commission, $\operatorname{COM}(2011) 206$ final, Brussels, 2011.

31 European Commission, Single Market Act II. Together for the new growth, Communication from the Commission, $\operatorname{COM(2012)~} 573$ final, Brussels 2012. 
a new growth put forward by the Commission are: developing fully integrated networks of transport and energy in the single market, fostering mobility of citizens and businesses across borders, supporting the digital economy across Europe and strengthening social entrepreneurship, cohesion and consumer confidence ${ }^{32}$. All key actions should now focus around these drivers.

\section{WHY THE ORIGINAL DREAM HAS NOT YET BEEN FULLY ACHIEVED? ${ }^{33}$}

According to The Cost of Non-Europe in the Single Market study of September 2014, drawn up by the European Added Value Unit ${ }^{34}$, the remaining untapped potential in the free movement of goods within the EU is worth 183 to 269 bln EUR of additional output per year (equivalent to 1.4 to $2.2 \%$ of EU28 GDP). It is despite the fact that the market of goods is already at a relatively advanced stage ${ }^{35}$. The same time a more deeply integrated single market in services could increase the level of long-run EU28 GDP by another 338 to 637 bln EUR (2.6 to 5\%). Nothing more than a fully functional and implemented Services Directive could yield gains of 0.3 to 1.5 percent of GDP per year in the long term ${ }^{36}$.

The identified gaps in the Digital Single Market cost 36 to 75 bln EUR per year ( 0.3 to $0.6 \%$ of EU28 GDP) ${ }^{37}$. Greater cross-border public procurement could allow annual savings of 36 to 66 bln EUR (0.3 to $0.5 \%$ of EU28

${ }^{32}$ Ibidem, p. 5.

${ }^{33}$ The question asked by José Manuel Barroso, President of the European Commission, in: J.M. Barroso, Political guidelines for the next Commission, http://ec.europa.eu/archives/commission_2010-2014/president/pdf/ press_20090903_en.pdf (14.08.2015).

${ }^{34}$ Z. Pataki, The Cost of Non-Europe in the Single Market. "Cecchini Revitised", An overview of the potential economic gains from further completion of the European Single Market, CoNE 1/2014, European Parliamentary Research Service, European Added Value Unit, PE 510.981, Brussels 2014.

35 Ibidem, pp. 15-16; 24-27. In case of Poland a removal of non-tariff barriers would mean a predicted profit of 7.553 mln EUR - change in trade and GDP of 6.71 and 1.98\%, respectively (for Germany - $35.883 \mathrm{mln}$ EUR, for the Netherlands - $22.359 \mathrm{mln}$ EUR).

${ }^{36}$ Ibidem, pp. 16-18; 27-28.

${ }^{37}$ Ibidem, pp. 19-20; 28-29. A deeper and more complete DSM means a single area for online payments, e-invoicing, protecting intellectual property rights etc. 
GDP $)^{38}$. Last but not least, incomplete consumer acquis brings consumers a loss of 58 bln EUR per year (0.45\% of EU28 GDP) ${ }^{39}$.

According to the study closing all gaps in the single market could yield gains of minimum 651 bln EUR per year (5.08\% of EU28 GDP). This fits with the "Cecchini Report" of 1988, which estimated the "cost of non-Europe" to be between 4.25 and $6.5 \%$ of EU12 GDP 40 . Furthermore, changes in the global economic environment and technological progress seem to indicate that at present the possibility of obtaining additional gains from the integration is even greater than in the past. If so, why building consensus around the single market is seemingly more difficult to achieve than ever in the past?

While the EU institutions meaning of life is to work for such consensus, in case of public authorities answer is not so obvious. One could say that their way of thinking is hereditarily burdened by the spirit of economic nationalism. They represent the interests of countries with different cultural traditions, concerns and political preferences, having therefore different approaches to the single market ${ }^{41}$. What's more, regardless of local specifics, in times of the crisis the tendency to protect their own interests and solve their own problems reveals with special strength.

The implementation of the national targeting policy gives public authorities a sense of independence and real power. They make their ability to carry out such policy from leaving at their disposal specific prerogatives and economic and legal instruments. This stands in stark opposition to the widely proclaimed goal of EU secondary legislation which is, in general, liberalization across the European economy. Specifically, this means, among others, stripping away government subsidies, government-created monopoly power, and other still existing legal barriers to trade and competition ${ }^{42}$.

Such protectionist approach of public authorities stems to a large extent from the specific behavior of citizens and businesses affected by the crisis.

${ }^{38}$ Ibidem, pp. 20-21; 29-30. Currently only around 3\% of all contracts in the EU are crossborder. The author notes that a mandatory e-procurement would not only save annually 50-75 bln EUR but would also increase transparency and public accountability.

${ }^{39}$ Ibidem, pp. 22-23; 30-31.

${ }^{40}$ P. Cecchini, M. Catinat, A. Jacquemin, The European Challenge 1992: The benefits of a Single Market, Aldershot: Wildwood House 1988. In fact, growth of GDP in 1987-1993 was much lower (1.3-1.5\%).

${ }^{41}$ Monti identified four such groups of Member States: continental social-market economy countries, Anglo-Saxon countries, Central and Eastern European countries, Nordic countries. See: M. Monti, op. cit., p. 7.

${ }^{42} \mathrm{HM}$ Government, Review of the Balance of Competences between the United Kingdom and the European Union. The Single Market, London 2013, https://gen/civilservice.gov.uk/, https:// www.gov.uk (15.08.2015). 
Willingness to give priority to solving local problems provides the authorities with satisfaction of electorate. In this situation, as it seems, only a clear support to the single market and its further integration shown by the majority of citizens of the Member States could change the approach of national authorities to clearly pro-EU. Otherwise they would not see this change as giving a real benefit for themselves (e.g. in the form of re-election).

The way in which EU citizens perceive the single market turns out to be the key problem. A report of May 2010, in which the European Parliament expresses its conviction that "the European citizens' perception, understanding and knowledge of the single market are low, non-existent, confused or even negative, in part because of a lack of political commitment and information and a low level of public awareness (...)" can be used for the reply ${ }^{43}$. The rapporteur, Louis Grech, commented in his Explanatory Statement to the report that "the already existing antipathy felt by consumers, citizens and SMEs towards the single market prior to the crisis, has post crisis been transformed into antagonism and gives way to economic protectionism of national markets" ${ }^{44}$. The "Monti Report" (published a few days later) argues in a similar vein, pointing to the erosion of the political and social support for market integration in Europe. According to Monti, distrust, fear and even hostility of many Europeans towards a single market stems from two mutually reinforcing trends: "an integration fatigue", eroding the appetite for more Europe and for a single market; and more recently, a "market fatigue", with a reduced confidence in the role of the market" ${ }^{45}$.

Unfortunately, the above assessments are still valid despite the fact that since then it's been five years - with the proviso that, contrary to earlier expectations, the crisis is not over and antipathy towards the single market is even greater than before.

\section{CONCLUSIONS}

According to Monti, from quite a long time in the EU increases a sense of complacency, as if the idea of the single market has already been carried out and thus, in a sense, could be pushed into the background by other priorities. In other words, "the single market was felt to be "yesterday's business",

${ }^{43}$ European Parliament, op. cit., p. 9.

${ }^{44}$ Ibidem, p. 17.

${ }^{45}$ M. Monti, op. cit., p. 6. 
in need of regular maintenance but not of active promotion" ${ }^{46}$. This sounds worryingly, especially in conjunction with the warning from the European Parliament that "the single market integration process is not irreversible" and that "the continued existence of the single market should not be taken for granted" 47 .

In 2001, the former US Trade Representative R.B. Zoellick directly commented on the implications of this type of situation in world trade, saying that if the trade liberalization process does not move forward, it will, like a bicycle, be pulled down by the political gravity of special interests ${ }^{48}$. This observation fits perfectly into the current state of the single market, requiring urgent revitalization to put a stop to such "special interests". However, this can prove difficult to achieve, despite the determination by the Commission of the specific levers to boost growth and strengthen confidence. The overview of responses to the public consultation on the EC communication Towards a Single Market Act clearly showed that there is a lack of consensus as to the most important challenges for the future of the single market - among six actions considered the most important by the citizens, not even one was in line with the six key priorities of the public authorities ${ }^{49}$. Therefore, it seems reasonable to conclude that without full implementation of the call by the European Parliament for the new paradigm focusing on citizens, consumers and SMEs in the relaunch of the European single market, runs out of momentum for further action. The single market will not move from the place if citizens and businesses do not believe in the project and not judge it as beneficial for them. And then the "bicycle theory" can turn to be true.

\section{BIBLIOGRAPHY}

Barroso J.M., Political guidelines for the next Commission, http://ec.europa.eu/archives/ commission_2010-2014/president/pdf/ press_20090903_en.pdf (14.08.2015).

Brussels European Council, Bulletin of the European Communities, No. 3/1985.

Cecchini P., Catinat M., Jacquemin A., The European Challenge 1992: The benefits of a Single Market, Aldershot: Wildwood House 1988.

${ }^{46}$ Ibidem, p. 6.

47 European Parliament, op. cit., p. 6.

${ }^{48}$ R.B. Zoellick, The WTO and New Global Trade Negotiations: What's at Stake, Council on Foreign Relations, Washington 2001.

${ }^{49}$ European Commission, Overview of responses to the public consultation on the Communication "Towards a Single Market Act", Commission Staff Working Paper, SEC(2011) 467, Brussels 2011, pp. 7-8. 
Commission of the European Communities, Completing the Internal Market. White Paper from the Commission to the European Council (Milan, 28-29 June 1985), $\operatorname{COM}(85) 310$ final, Brussels, 14 June 1985.

Council directive of 24 June 1988 for the implementation of Article 67 of the Treaty (88/361/EEC), OJ L 178

den Boer M., Step by Step Progress: An Update on the Free Movement of Persons and Internal Security, http://www.infoeuropa.eurocid.pt/files/database/000024001-000025000/000024994.pdf (09.08.2015).

Dublin European Council, Bulletin of the European Communities, No. 12/1984.

European Commission, Overview of responses to the public consultation on the Communication "Towards a Single Market Act", Commission Staff Working Paper, SEC(2011) 467, Brussels 2011.

European Commission, Single Market Act II. Together for the new growth, Communication from the Commission, COM(2012) 573 final, Brussels 2012.

European Commission, Single Market Act. Twelve levers to boost growth and strengthen confidence. Working together to create new growth, Communication from the Commission, COM(2011) 206 final, Brussels, 2011.

European Parliament, Report on delivering a single market to consumers and citizens (2010/2011(INI)), Session document, Committee on the Internal Market and Consumer Protection, Brussels 2010.

Fountainebleau European Council, Bulletin of the European Communities, No. 6/1984.

HM Government, Review of the Balance of Competences between the United Kingdom and the European Union. The Single Market, London 2013, https://gcn/civilservice.gov.uk/, https://www.gov.uk (15.08.2015).

Judgment of the Court of May 22, 1985, C-13/83.

Monti M., A new Strategy for the Single Market. At the Service of Europe's Economy and Society, Report to the President of the European Commission, 9 May 2010, http:// ec.europa.eu/internal_market/strategy/docs/monti_report_final_10_05_2010_ en.pdf (11.08.2015).

Pataki Z., The Cost of Non-Europe in the Single Market. "Cecchini Revitised", An overview of the potential economic gains from further completion of the European Single Market, CoNE 1/2014, European Parliamentary Research Service, European Added Value Unit, PE 510.981, Brussels 2014.

The European Council, Conclusions. Session of the European Council, Copenhagen, 3 and 4 December 1982, Dossier of the Group of the European People's Party, Luxembourg 1990.

Zoellick R.B., The WTO and New Global Trade Negotiations: What's at Stake, Council on Foreign Relations, Washington 2001. 